IBDA': Jurnal Kajian Islam dan Budaya

ISSN: 1693-6736; E-ISSN: 2477-5517

DOI: $10.24090 /$ ibda.v20i1.5895

Vol. 20, No. 1, Januari-Juni 2022, page 1-24

\title{
Students Resilience Through Reciting Hizib Sirrul Mashun as A Living Qur'an Tradition in Pondok Pesantren Al-Hidayah Purwokerto
}

\author{
Alief Budiyono \\ UIN Prof. K.H. Saifuddin Zuhri Purwokerto \\ Jl. A. Yani No. 40 A, Purwokerto, Kabupaten Banyumas, 53126 \\ alief@uinsaizu.ac.id
}

Abstract: This article examines the reciting Hizb Sirrul Mashun as a living Qur'an tradition at Pondok Pesantren Al-Hidayah, Purwokerto. It is field research with a descriptive-qualitative method, and the researcher gets research data through in-depth interviews, observations, and studies of related documents. He uses data reduction, display data, and conclusions in analyzing data. The results are, First, students (Santri) recite Hizb Sirrul Mashun during Coronavirus disease (COVID-19) pandemic whose goal is a dynamic process of positive adaptation to adversity, Second, fasting for seven consecutive days - for students who are just practicing. During the implementation process, if the students fail both in reciting the Hizb or the fast, They repeat it from the beginning. The senior student leads the reciting at the An-Nur Karangsuci Mosque. Practically, the students recite Hizb Sirrul Mashun at the Pondok Pesantren Al-Hidayah Karangsuci Purwokerto after the congregational evening prayer on Friday night. Third, based on the Sociological theory of Karl Mannheim, the meaning contained in the reciting of Hizb Sirrul Mashun includes three aspects, namely objective, expressive, and documentary. The objective meaning emphasizes that the reciting of Hizb Sirrul Mashun is also strongly influenced by the social support implemented in Kyai's words. One of the factors supporting resilience is social support. The expressive meaning from the students (Santri) emphasizes that other factors influence the formation of resilience, namely religiosity and spirituality.

Keywords: Resilience, Santri, Pondok Pesantren Al-Hidayah, Hizb Sirrul Mashun 


\section{A. Introduction}

Many pondok pesantren in Indonesia currently are practicing Hizb, and it becomes a routine activity as a prayer to Allah SWT. One of pondok pesantren is Pondok Pesantren al-Hidayah Karangsuci Purwokerto through the Hizb Reciting Tradition which is carried out by the students (Santri) regularly. The scholars call this Hizb with various names. Those who adhere to the Sufism of Imam Al-Ghozali and adherents of the Qadiriyah order call this Hizb "Hizb Al-Ghozali" - by referring to its author, Abu Hamid AlGhazali. In addition, some groups call it "Hizb Sirr Al-Mashun" because it has many secrets, benefits and virtues.

In addition to the two names, followers of the Rifaiyah order and groups who think that this Hizbcame from Sheikh Abdul Qadir Al-Jailani called this Hizb "Hizb Saif Al-Qathi." Reciting the Hizb is the same as reciting the AlQur'an because it also contains a lot of verses from the Al-Qur'an. In addition, it is an effort to protect oneself from various calamities or dangersespecially during the COVID-19 pandemic.

The Covid-19 pandemic initially attacked Wuhan, China, at the end of 2019. Several countries, including Indonesia, considered Covid-19 cases as a common problem. However, Covid-19 began to develop in early January 2020, when this virus attacked various countries such as Indonesia. The Covid-19 case in Indonesia occurred in early February 2020, at which time the number of confirmed Covid-19 patients showed const antly significant numbers. Moreover, many medical personnel have died due to Covid-19. Based on these facts, the spread of Covid-19 in Indonesia is getting out of control. It affects Indonesia's status with the highest positive confirmed patients.

Banyumas is a Regency located on the west side of Central Java Province. Banyumas is one of the districts with a significant intensity of positive Covid-19 cases. One of the reasons for the high number of Covid-19 cases in Banyumas is the positive case in Islamic boarding schools or Pondok Pesantren, one of which is Pondok Pesantren Al-Hidayah Karangsuci Purwokerto. From the data obtained, there are at least 500 students (Santri) confirmed positive for COVID-19 at Pondok Pesantren Al-Hidayah Karangsuci Purwokerto. Some of these students are undergoing isolation at the Banyumas Regional General Hospital (RSUD), Margono Soekardjo Hospital Banyumas, or in isolation places prepared by the Banyumas Regency Government. 
Alief Budiyono: Students Resilience Through Reciting Hizib Sirrul Mashun as A Living Qur'an Tradition in Pondok Pesantren al-Hidayah... (page 1-24)

The researcher is interested in studying the resilience of students (Santri) at Pondok Pesantren Al-Hidayah Karangsuci Purwokerto in the face of the COVID-19 pandemic through the living Qur'an tradition, specifically the reciting of Hizb sirrul mashun. Hizb itself is a prayer taught by the Prophet SAW and particular words recited at certain times. Functionally, Hizb itself usually serves to reject or face various major disasters or enemy threats.

Resilience itself is an individual's effort to adapt well to stressful conditions, and he can recover and perform his best functions and survive adversity (Waxman \& Yolanda, 2013). In general, resilience depends on factors related to stress and adaptation results when individuals experience difficulties (Missasi \& Izzati, 2019). According to Diclemente, Santelli, and Crosby (Diclemente \& John, 2009), resilience has a close relationship with stress conditions in individuals, unseparated two aspects. Resilience can occur when individuals are in a depressed condition that triggers stress, so stress management is necessary as a positive adaptation process (Budiyono et al., 2020). Therefore, as previously stated, this article attempts to elaborate on students' resilience through reciting Hizb sirrul mashun at Pondok Pesantren Al-Hidayah Karangsuci Purwokerto during the covid-19 pandemic.

\section{B. Research Methods}

Following the research objectives, this research is qualitative research and field research. The researcher uses the descriptive-qualitative method because the method is appropriate to the subject. In addition, the output of qualitative research is a finding whose results are undescribed and unexplained by statistical methods (Soehadha, 2012).

The researcher collects data to interact directly with the object or community. A natural approach and sensitivity to current social phenomena is a must for researchers because the accuracy of the research is highly dependent on data in the field. Objectivity in recording empirical data is a necessity. It aims to facilit ate the analysis carried out to conclude (Salim \& Syahrun, 2012).

In qualitative research, the subject is an informant who is a consult ant to obtain research data needed by the researcher. The sample selection does not depend on probabilistic sampling technique but purposive sampling technique. In other words, the researcher brings into line the sample selection to the assumption of ideal data, which Salim and Syahrun call criterion-based sampling (Salim \& Syahrun, 2012). In conducting the research, the researcher 
made students in Pondok Pesantren Al-Hidayah Karangsuci Purwokerto the subject and made the tradition of reciting Hizib sirrul mashun the object.

\section{The Results And discussion}

\section{Research Object}

a) A Brief History: Establishment and Development

Depending on a notarial deed No. 69 dated 10 September 1957, fonding year Pondok Pesantren the Al-Hidayah was 1957. The establishment of this Pondok Pesantren was the idea of KH. Muslih realized and authorized by Prof. KH. Anwar Musaddad - one of the PBNU administrators (Hidayatullah, 2017). The name Al-Hidayah is the name given by the Leader of Pondok Pesantren Lasem Rembang, namely K.H. Maksum. KH. Dr. Noer Hadi Iskandar al-Barsany, MA., and Nyai Dra. Hj. Nadhiroh lead this Pondok Pesantren by adopting the learning system of Pondok Pesantren Mamba'ul Ulum Mberasan Banyuwangi. The vision of Pondok Pesantren Al-Hidayah is to maintain and protect the teachings of Sunni Islam. This vision refers to the hopes of Syaikhs so that students (Santri) have the ability and willingness to study the salaf ulama's guidances and teachings in some classical literature (Kitab Kuning). The purpose of studying the teachings of Sunni Islam is to form students who have good morals based on four principles, namely tolerance (tasamuh), moderate (tawassut), balance (tawazun), and reasonableness (i'tida).

In its development, Al-Hidayah became a fast-growing and well-known Pondok Pesantren. Al-Hidayah became a pesantren that persisted and attracted students from both Banyumas and outside Banyumas to acquire religious knowledge. Heretofore, the number of Al-Hidayah students has reached 500 students (Santri) and has graduated thousands of students spread across various regions (Hidayatullah, 2017).

\section{b) The Purposes of Pondok Pesantren}

Pondok Pesantren Al-Hidayah Karangsuci Purwokerto aims to (Zaman, 2019):

1) Form Muslim intellectuals who have superior quality, master the religious sciences, provide benefits to society, and can apply them in social life. 
Alief Budiyono: Students Resilience Through Reciting Hizib Sirrul Mashun as A Living Qur'an Tradition in Pondok Pesantren al-Hidayah... (page 1-24)

2) Develop and disseminate knowledge based on Islamic values.

3) Support creating a conducive, accountable, transparent, and democratic environment in the practice of education in Pondok Pesantren so that they can create a quality and effective generation.

\section{c) Programs}

This institution, located in Banyumas, has a pesantren education program which can be classified into 3 (three) programs. The first is Madrasah Diniyah Salafiyah Al-Hidayah. This madrasa is a program for Santri who are university students, either from UIN Prof. K.H. Saifuddin Zuhri Purwokerto, Jenderal Sudirman University (Unsoed), Nahdlatul Ulama University Purwokerto, and other universities around Purwokerto. The second is Madrasah Diniyah Al-Kautsar or MDA (Zaman, 2019). This madrasa is a program for Santri with student status around Purwokerto. The third is Madrasah Qur' aniyyah Al-Hadi which accommodates learning of the Al-Qur'an for both senior High School students and university students. The details are as follows: The first is Madrasah Diniyah Salafiyah Al-Hidayah. This madrasa is a pesantren-based religious education institution. This institution is a forum for students who are not only studying religious knowledge. They can also develop their intellectual power through science, social science, and other science. The output of MDSA is Santri who can assist and guide the community towards civil society and create a blessed country (baldatun thayyibatun wa rabbun ghafur).

The madrasa is led by Ustadz Biqih Zulmy, S.Pd. This program has a study process of 5 years with 1 year of preparatory class or I'dadiyah-now called 1 Tsanawiyah. In its activities, MDSA is handled by teachers from various well-known Pondok Pesantren such as Pondok Pesantren Al-Falah Ploso Mojo, Pondok Pesantren Hidayatul Mubtadi'ien Lirboyo, and Pondok Pesantren API as-Salafi Tegalrejo Magelang. The focus of the study from this institution is the books of the saläf (kitab kuning) about tärich (Islamic history), jurisprudence, linguistics (nahwu, saraf, balaghah), and logic (mantiq). The lesson timetable and its tutor are in the appendix (Zaman, 2019).

The second is Madrasah Diniyah al-Kautsar. Like MDSA, Madrasah Diniyah al-Kautsar is also a madrasa under the auspices of the Pondok Pesantren Al-Hidayah Karangsuci Purwokerto. The difference with MDSA 
is that this institution takes care of Santri as a university student. MSDA emerged from the fear of teachers in the current young generation who are increasingly moving away from cultural and Islamic values. Therefore, to answer these problems, Madrasah Diniyah al-Kautsar became a solution by studies of salaf books that produced students who can master and answer religious issues in society (Santri 1, personal communication, 2020).

The leader of this institution is Ust. Gamelan, S.Pd. The length of education at this institution is three years. This institution focuses on studying the moral sciences, tajwid, and Islamic theology (Zaman, 2019).

The third is Madrasah Qur'aniyyah Al-Hadi. Madrasah Qur'aniyyah alHadi is an institution under the auspices of Al-Hidayah Karangsuci Purwokerto which is engaged in the study on the science of the Al-Qur'an. The word al-Hadi comes from the name of its leader, namely KH. Dr. Noer Hadi Iskandar al-Barsany (Santri 2, personal communication, 2020).

This institution regulates all activities related to the study of the AlQur'an (Santri 2, personal communication, 2020). There are three groups in the Institute for studying the Al-Qur'an at Al-Hidayah: The first is the study of the Al-Qur'an for students. This study is for Santri whose status is a student in high school. In the learning process, the material provided is almost the same as the material for students who follow matriculation. The second is an assessment for students from various universities. It is an institution for Santri who are university students in Purwokerto. The materials presented were: deposit for reciting the Al-Qur'an 30 juz bi an-Nazri and bi al-ghaib and the study of the Book of Tafsir Jalalain. The third is the study of the Al-Qur'an for students who take part in the matriculation of BTA PPI UIN Prof. K.H. Saifuddin Zuhri Purwokerto, and he is predicated that he has not passed the BTA PPI exam. In the PPI BTA study process, there were several lessen such as tajwid, Tahsin (improvement of reading), and memorizing the Al-Qur'an (Santri 3, personal communication, 2020).

Pondok Pesantren Al-Hidayah implements the Sorogan learning system (musyäfahah) and the bandongan system ('arud). The Sorogan system is a system of studying the Al-Qur'an in which students recite the Al-Qur'an in front of the teacher, and then the teacher will correct the reading if there are errors. The Bandongan system is an assessment system carried out in the same place with the teacher (Santri 4, personal communication, 2020). 
Alief Budiyono: Students Resilience Through Reciting Hizib Sirrul Mashun as A Living Qur'an Tradition in Pondok Pesantren al-Hidayah... (page 1-24)

\section{d) Activites in Pondok Pesantren Al-Hidayah Karangsuci Purwokerto}

1) Daily Activities

The schedule of daily activities at the Al-Hidayah Karangsuci Islamic Boarding School in Purwokero is as follows (Zaman, 2019):

Table 1. Santri Daily Activities

\begin{tabular}{|l|l|}
\hline Time & Activities \\
\hline $03.30-05.00 \mathrm{WIB}$ & $\begin{array}{l}\text { Wake up, tahajjud prayer, aurad qabliyah } \\
\text { subuh, Fajr prayer in congregation at the } \\
\text { Mosque An-Nur and dzkir }\end{array}$ \\
\hline $05.00-07.00 \mathrm{WIB}$ & $\begin{array}{l}\text { Depositing memorization of the koran bi an- } \\
\text { nazri dan bi al-ghaib, sorogan the book of salaf } \\
\text { scholars (kitab kuning), and Study of the Book } \\
\text { of Tafsir Jalalain. }\end{array}$ \\
\hline $07.00-12.30 \mathrm{WIB}$ & $\begin{array}{l}\text { Teaching and Learning Activities (KBM) in } \\
\text { the class or formal school (middle school and } \\
\text { high school students) }\end{array}$ \\
\hline $12.30-13.00 \mathrm{WIB}$ & Zuhr prayer \\
\hline $13.00-15.30 \mathrm{WIB}$ & Rest and Eating \\
\hline $15.30-16.15 \mathrm{WIB}$ & $\begin{array}{l}\text { Asr prayer and reciting al-waqi'ah at the } \\
\text { Mosque an-Nur. }\end{array}$ \\
\hline $16.15-17.15 \mathrm{WIB}$ & Teaching and Learning Activities (KBM) \\
\hline $17.00-17.30 \mathrm{WIB}$ & $\begin{array}{l}\text { Taking a bath and preparing for Maghrib } \\
\text { prayer in congregation }\end{array}$ \\
\hline $18.15-19.45 \mathrm{WIB}$ & $\begin{array}{l}\text { Maghrib prayer in congregation, reciting yasin } \\
\text { together, public lecture the book of Fathul } \\
\text { Mu'inn, Depositing memorization of the koran } \\
\text { bi an-nazri dan bi al-ghaib. }\end{array}$ \\
\hline $19.45-20.15 \mathrm{WIB}$ & Isha prayer \\
\hline $20.15-21.15 \mathrm{WIB}$ & Madrasah Diniyah \\
\hline $21.15-21.45 \mathrm{WIB}$ & Rest and Lunch \\
\hline $21.45-22.45 \mathrm{WIB}$ & Extracurricular and tutoring \\
\hline $22.45-03.15 \mathrm{WIB}$ & Rest \\
\hline $03.15-04.00 \mathrm{WIB}$ & Qiyam al-Lail, suhoor (for those who will fast) \\
\hline & \\
\hline
\end{tabular}


2) Weekly Activities

The schedule of weekly activities at the Al-Hidayah Karangsuci Islamic Boarding School in Purwokero is as follows (Zaman, 2019):

Table 2. Santri Weekly Activities

\begin{tabular}{|l|l|l|l|}
\hline No & Activities & Day & Place \\
\hline 1 & $\begin{array}{l}\text { Study the book of salaf } \\
\text { scholars (Stadium } \\
\text { General) }\end{array}$ & Friday night & Masjid An-Nur \\
\hline 2 & Muräja'ah Juz 30 & $\begin{array}{l}\text { Sunday } \\
\text { morning }\end{array}$ & Masjid An-Nur \\
\hline 3 & $\begin{array}{l}\text { Al-barjanji or sema'an } \\
\text { (listening the koran) }\end{array}$ & $\begin{array}{l}\text { Friday } \\
\text { morning }\end{array}$ & $\begin{array}{l}\text { The Hall of Each } \\
\text { Dormitory }\end{array}$ \\
\hline 4 & $\begin{array}{l}\text { Reciting Hizib Sirrul } \\
\text { Masūn }\end{array}$ & Friday night & Masjid An-Nur \\
\hline
\end{tabular}

3) Annual Activities

The schedule of Annual activities at the Al-Hidayah Karangsuci Islamic Boarding School in Purwokero is as follows (Zaman, 2019):

Table 3. Santri Annual Activities

\begin{tabular}{|c|c|c|c|}
\hline No & Activities & Time & Place \\
\hline 1 & $\begin{array}{l}\text { Khotmil Qur'an in } \\
\text { commemoration of the } \\
\text { Islamic New Year }\end{array}$ & 1 Muharram & \multirow{4}{*}{$\begin{array}{l}\text { The yard of Pondok } \\
\text { Pesantren Al- } \\
\text { Hidayah Karangsuci } \\
\text { Purwokerto }\end{array}$} \\
\hline 2 & $\begin{array}{l}\text { The birthday of the } \\
\text { Prophet Muhammad }\end{array}$ & $\begin{array}{l}12 \text { Rabi’ul } \\
\text { Awal }\end{array}$ & \\
\hline 3 & $\begin{array}{l}\text { Grand Lecture in the } \\
\text { commemoration of Haul } \\
\text { Masyayikh, Mu'assis } \\
\text { Ma'had and the } \\
\text { community }\end{array}$ & $\begin{array}{l}\text { The month } \\
\text { of Rojab }\end{array}$ & \\
\hline 4 & $\begin{array}{l}\text { Khatmil Kitab and Akhir } \\
\text { al-sanah }\end{array}$ & $\begin{array}{l}\text { The month } \\
\text { of Rojab }\end{array}$ & \\
\hline
\end{tabular}


Alief Budiyono: Students Resilience Through Reciting Hizib Sirrul Mashun as A Living Qur'an Tradition in Pondok Pesantren al-Hidayah... (page 1-24)

\section{Hizib Tradition as Reception (living) of the Qur'an: Epistemological Review}

The Al-Qur'an is the source of Islamic religious teachings. This holy book is not merely the first source of law that has a central role in Islamic teachings. It is also a way of life for Muslims since the movement of the Ummah for 14 centuries. The Al-Qur' an is also the last divine book. Every Muslim believes that the Al-Qur'an is a holy book whose authenticity is guaranteed directly by Allah SWT.

The Qur' an declares itself as a guide (Huda) that functions to transform humans from darkness (Zulumat) to light (Nur) (Zaman, 2020). Therefore, the Qur'an must be a dynamic entity, not static only used as an aesthetic function. Furthermore, it is only to deviate from Islamic law.

There is an undeniable fact that although the Qur'an uses Arabic. However, it must operate as a guide (Huda) for all people - not exclusively for Arabs. Therefore, the existence of the Al-Qur'an hopefully can awaken Muslims to explore the interpretation and development of the meaning of each verse. In the next stage, it affects the intellectual odyssey of Muslims (Hidayat, 1996). In addition, the process of understanding the Al-Qur' an will always face two realities, namely the text and the context. Therefore, logically, there will always be dialectic between the two realities.

According to Ibn Taymiyyah's view on the Al-Qur'an, at the epistemological level, reason and revelation have a harmonious position. He removed the contradiction between reason and revelation. From an epistemological perspective, reason functions to understand the meaning contained in the Qur'an. In this case, it must explain and provide scientific evidence. The only guidelines for making laws are the Al-Qur' an and the Sunnah of the Prophet Muhammad (Ilyas, 2004). The Al-Qur'an plays a significant role as a guide for all people in the world, not only for the Arabs. The Al-Qur'an is very close to the community, but many people do not understand Arabic (Imzi, 2017).

While in another reality, the growing enthusiasm for Muslims in the last decade. In the perspective of Islamic studies, the existence of the Al-Qur'an is exciting but also worrying. Because, as a text, the Al-Qur'an cannot explain its contents to us, but through an interpreter of the Qur'an (Rijal Qur'an). The interpreter itself requires general rules or principles to draw clear conclusions. The understanding of the verses of the Al-Qur' an is correct, even though it is relative because absolute truth belongs only to God (Imzi, 2017). 
The Al-Qur'an is beneficial for all people. It is like the ocean; Its water does not dry up, its waves are endless, and its wealth will never run out. It will be useful for many things. The Al-Qur' an is scripture (holy book) and miracles of Muslims. It has a position as the source, a source of religion, a source of values, a source of motivation and inspiration, and a source of all laws in life. Those who believe in The Al-Qur'an will not feel bored.

The historical narratives contained in the Al-Qur' an not only record the socio-economic, religious, ideological, political, and cultural conditions of human civilization before the 7th cent ury AD. However, at the same time, it also acts as a guide for humans. Thus, the interpretation of the Al-Qur' an plays an essential role in the progress and decline of the ummah. It acts as a key to opening the storehouse contained in the Al-Qur'an (Shihab, 1999). Ibn Qayyim al-Jauzi said in the book Zaad Al-Ma'ad volume 4 page 322:

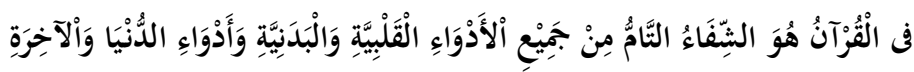

“The Qur'an is a perfect healing medium for all heart and physical diseases, diseases in this world and the hereafter." (Qayyim, n.d.)

Jalaluddin As-Suyuthi more explained in his book entitled Al-Itqaan Fii Ulum Qur'an by writing a chapter on the "benefits of the Qur'an." Jalaluddin As-Suyuthi, in his book, quotes a hadith of the Prophet Muhammad conveyed by Abdullah bin Imam Ahmad bin Hanbal in the book Zawaaid al-Musnad. Rasulullah SAW said:

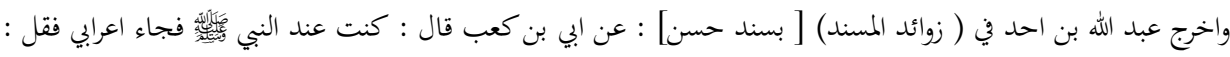

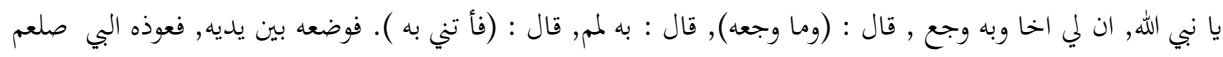

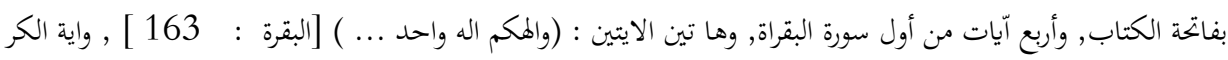

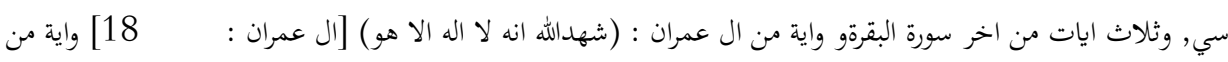

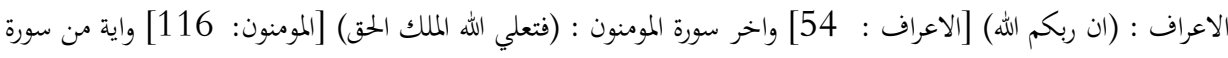

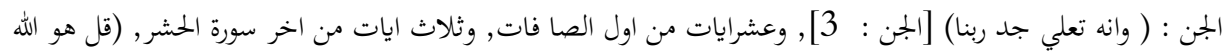

$$
\begin{aligned}
& \text { أحد) المعودتين, فقام الرجل كأنه مل ميشك قط. }
\end{aligned}
$$

Imam Abdullah bin Ahmad in the book Zawaid Al-Musnad with the Hasan Sanad transmitted from Ubay bin Ka' ab when he was beside the Prophet. Then a Bedouin Arab came and said: "O Nabiyullah, I have a brother who is sick." Then the Prophet said, "What is the disease?" Ubay said, "He's a bit crazy." The Prophet said, "Bring your brother here, then the Prophet put his 
Alief Budiyono: Students Resilience Through Reciting Hizib Sirrul Mashun as A Living Qur'an Tradition in Pondok Pesantren al-Hidayah... (page 1-24)

hands, and he prayed with the Qur'anic verse consisting of QS. Al-Fatihah, the beginning of Surah Al-Baqarah (4 four verses) "Wa Ilaa Hukum Ilaahuwwaahid," Throne Verse (Surah Al-Baqarah: 256), End of Surah AlBaqarah (three verses), QS. Ali-Imran: 18, QS. Al-A'raf: 54, QS. AlMu'minun: 116, QS. Jin: 3, QS. Ash-Shofat (10 verses), the end of Al-Hasyr (3 verses), Al-Ikhlas, $\mathrm{r}$ Al-Muawwizatain. then the man stood up as if he had never complained at all (As-Syafi'i, n.d.). (Narrated by Abdullah bin Ahmad).

This hadith is the statement of the many hadiths conveyed by some scholars regarding Quranic verses as an antidote to various diseases. Some of them are in Hizb. Suyuthi in his book Al-Itqaan Fii Ulum Qur'an (As-Syafi'i, n.d.), adds that:

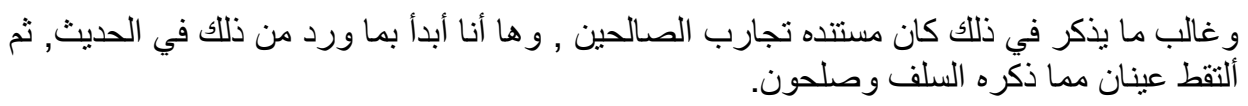

"Most of the prayers from the Al-Qur'an (including the Hizb) come from the tested practice of the scholars (Mujarrab). Remember that I started the chapter on the benefits of the Al-Qur' an following the hadith, then I recited what was recited by previous scholars."

Hizbun is the root word of the word Hizb. It means party, group, class, type, dhikr, division, army, troop, or weapon. In this context, Hizbun is a kind of dhikr, which in everyday language is called Hizb (Umar, 2010). Hizb is a collection of Quranic verses and dhikr. It does not only contain praise to Allah and prayers to the Prophet alone. However, it consists of prayers to ask forgiveness and help from Allah. The way to practice Hizib is to recite it over and over again. It aims to draw closer to Allah (Taqarrub Illallah).

In Hizb, there are several quotes from the Al-Qur'an, and they are sometimes not related to the previous series of prayer pronunciations. It is an example that Hizib has many secrets (Sirr) that are difficult for the general public to understand. Some scholars who master Hizb argue that the selection of certain verses in the Al-Qur'an depends on Asbabun Nuzul or the reasons for the revelation of particular verses following the context of reciting prayers in Hizb (Umar, 2010).

There are several types of hizb that are well known in Islamic boarding schools in Indonesia, such as: Hizb Nawawi; Hizb Bari; Hizib Bahri; Hizb Bukhari; Hizb Darul A’la by Muhyiddin Ibn ‘Arabi; Hizb Zajr by Imam Tijani; Hizb Nashar by Imam Abu Hasan Asy-Syazali; Hizb Ikhfa by Imam Abu 
Hasan Asy-Syazali; Hizb Sakran by Imam Abubakar Assakran bin Al Hafidh Al Musnid Al Imamsafurrah hatta Hizb sirrul mashun; Hizb Nashar by Imam Abdullah bin 'Alawi Al-Haddad (Abdullah, 2012).

\section{Student Resilience Through Tradition of Reciting Hizb Sirrul Mashun in the Covid-19 Pandemic Period}

Resilience is an effort made by individuals to encourage themselves to rise again after experiencing one or many problems to continue a better life (Rutter, 2006). Resilience in its development is not only related to individual and genetic factors. However, resilience is also influenced by culture and the surrounding environment. An individual's behavior is largely influenced by genetics. However, in practice, cultural factors affect individual resilience, both increasing or decreasing the level of resilience (Wong et al., 2006). Reivich and Shatte also add that resilience is a person's effort to overcome the problems he is experiencing (Reivich \& Shatte, 2002).

Resilience in individuals depends in part on several factors. The first is spirituality. Spiritual is an internal drive that determines and increases resilience in individuals (Reisnick et al., 2011). It corresponds to Jurjewicz's study on Muslim immigrants (2016), "How spirituality leads to resilience a case study of immigrants." Based on this research, spirituality and resilience are two aspects that are interrelated and unseparated (Jurjewicz, 2016).

The second is Self Efficacy. Self-efficacy is related to a person's perception of the abilities they have. Self-efficacy makes a person's level of resilience varies. The third is optimism. Reivich and Shatte (2002) state that one of the factors that influence resilience is optimism (Reivich \& Shatte, 2002). Research conducted by Molinero, Zayas, Gonzalez, and Guil (GomezMolinero et al., 2018), with a sample of 132 students in Spain, supports Reivich and Shatte's study. The literature on resilience explains how students successfully adapt at university. Resilience is an individual's ability to adapt in the face of adversity. Optimism is one way to increase resilience for getting positive results in the fut ure.

Fourth is self-esteem. Reisnick, Gwyther, and Roberto (2011) say that self-esteem affects resilience. The statement corresponds with the research conducted by Veselska, Geckova, Orosova, and Gajdosova (Veselska et al., 2009). Veselska et al. conducted a study on 3694 male and female adolescents with an average age of 14.3 years, and the study showed that self-esteem 
Alief Budiyono: Students Resilience Through Reciting Hizib Sirrul Mashun as A Living Qur'an Tradition in Pondok Pesantren al-Hidayah... (page 1-24)

affects resilience in adolescents. Based on this research, self-esteem in males is at a low level when they use cigarettes and marijuana as a form of their resilience. Fifth is social support. Reisnick, Gwyther, and Roberto add that social support is a factor that affects resilience in individuals.

The Covid-19 pandemic affects the welfare of all human beings in the world (Wu et al., 2020). The spread of the COVID-19 virus in various countries has caused numerous negative impacts. A person infected with the COVID-19 virus experiences damage to the cardiovascular system (Madjid et al., 2020), pneumonia (Jin et al., 2020), and even death (Barro et al., 2020).

Many countries have taken a handling strategy to deal with this case as a new reality. It is to minimize the prolonged Covid-19 Pandemic in the community. Individuals must adapt when facing a stressful environment (Adler \& Saboe, 2017). Psychological resilience in individuals during the Covid-19 pandemic serves to deal with and reduce the impact of stress. Therefore, by reciting Hizb Sirrul Mashun, Santri carry out a dynamic process to actively adapt to difficulties during the Covid-19 pandemic.

On a practical level, new students (Santri) who will fulfill the requirements carry out this tradition by fasting for seven consecutive days and students who have fulfilled the requirements to recite Hizb seven times a day. During these seven days, students must continue to fast and recite Hizb. If not, the Santri must repeat the fast and the reciting from the beginning again. Senior Santri lead the reciting of Hizb Sirrul Mashun in the mosque (Santri 5, personal communication, 2020).

The series of reciting Hizb Sirrul Mashun at Pondok Pesantren AlHidayah Karangsuci Purwokerto were carried out on Friday night after the congregational evening prayer. In detail, this is the procession of reciting Hizb Sirrul Mashun at Pondok Pesantren Al-Hidayah Karangsuci: The first is reciting Tawasul. The recitation of Tawasul is addressed to the Prophet and his family, his companions, all Muslims, and Masyaikhs. Here is the Tawasul for reciting Hizb Sirrul Mashun: 


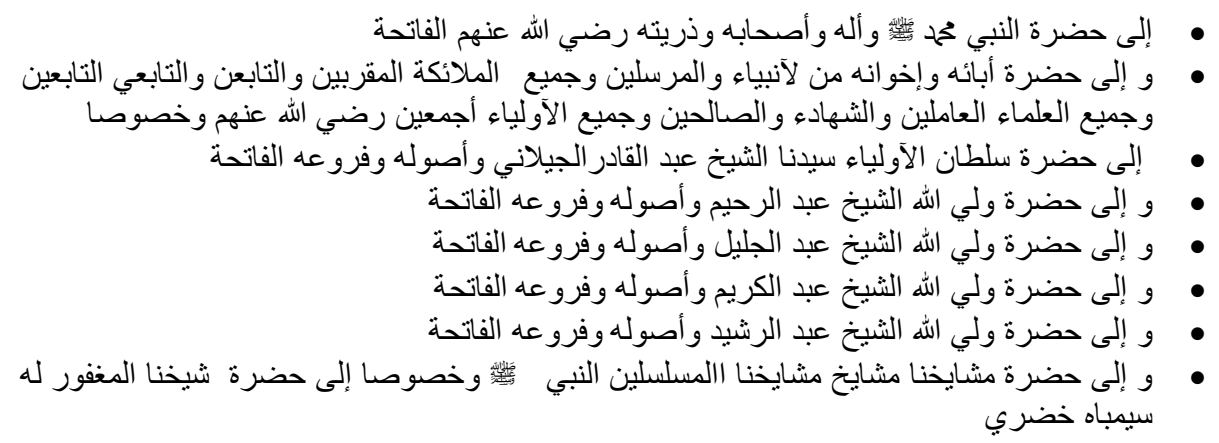

For Muslims, Tawasul is a way to get closer to Allah (Taqarrub Illallah). In essence, the final orientation of Tawasul is Allah. The people we use for Tawassul become Wasilah (intermediary or means) to get closer to Allah (Maliki, n.d.). The normative argument of Tawasul is al-Maidah: 35.

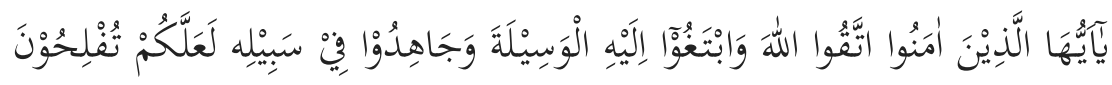

O you who have believed, fear Allah and seek the means [of nearness] to Him and strive in His cause that you may succeed.

In the perspective of Usul Fiqh (Principles of Islamic jurisprudence), the word al-Wasilah in this verse is universal ( 'Amm). Therefore, the word carries the meaning of various means. The word al-Wasilah can mean something that Allah has made a means to get closer to Him. It aims to obtain Maqsad from Him. Al-Wasilah must have a noble position in the sight of Allah SWT. Therefore, al-Wasilah in this verse includes various means such as prophets and pious people (Shalihin) or others such as righteous deeds.

The second is to recite Al-Fatihah 41 times. It is after the reciting Tawasul led by the Imam. Al-Fatihah is a surah that has many virtues. Therefore, Al-Fatihah is called Umm al-Kitab (the Mother of the Book). Reciting Surah Al-Fatihah has benefits. This information is in one of the hadiths narrated by Imam Bukhari, Rasulullah SAW said:

"Do you want me (the Prophet) to teach you the noblest letter in the AlQur' an before you leave the mosque?" He then continued, "Alhamdulillahirobbil'alamin and the Al-Azim Qur'an that has been given to me."

The hadith contains the meaning that the Prophet SAW in his words emphasized that the Surah Al-Fatihah has a noble position in the Al-Qur'an so that it has another name, namely the mother of the Al-Qur'an. Therefore, 
Alief Budiyono: Students Resilience Through Reciting Hizib Sirrul Mashun as A Living Qur'an Tradition in Pondok Pesantren al-Hidayah... (page 1-24)

reciting Al-Fatihah in the Hizib Sirrul Mashun procession is an important procession because it is a noble surah.

After reciting Surah al-Fatihah 41 times, the students recite Hizib Sirrul Mashun once. An Imam who is a teacher at Pondok Pesantren Al-Hidayah Karangsuci Purwokerto led the reciting together. Hizb Sirrul Mashun is in the appendix. The fourth or last is the reciting Hizb Sirrul Mashun, ending with the reciting particular prayer.

\section{The Meaning of Reciting Hizib Sirrul Mashun at the Al- Hidayah Islamic Boarding School Karangsuci Purwokerto during Pandemic Covid 19}

Kalmanheim pointed out that there are at least two dimensions in human behavior. The two dimensions are the external behavioral dimension and the meaning dimension. Therefore, when a social scientist wants to understand social behavior, he must also examine the meaning of these external behaviors. Mannheim divides the meaning of behavior into three typologies, namely objective meaning, expressive meaning, and recorded meaning (Mannheim, 1954).

The researcher conducted interviews and direct observations with main informants involved in the tradition. The researcher interviewed several sources, namely Nyai Dra. Hj. Nadhiroh. The other resource persons were male students and female students involved in the reciting Hizb Sirrul Mashun.

From the objective side, the meaning of reciting Hizb Sirrul Mashun is a meaning determined by the social background in which the behavior occurs (Mannheim, 1954). To obtain objective meaning, the researcher must observe directly the conditions of the social background that influence it. Therefore, through objective meaning, he can find the authentic meaning of social environmental conditions that affect the meaning of reciting Hizb Sirrul Mashun. In this case, it is the behavior of the students in Pondok Pesantren Al-Hidayah Karangsuci Purwokerto.

From an objective perspective, Hizb Sirrul Mashun in the Pondok Pesantren started with the reciting of the Hizb by Abah Noer Hadi Askandar al-Barsany. He got this Hizb from his parents and teacher, Kyai Askandar, while studying at Manbaul Ulum Banyuwangi.

In addition, the Kyai of the Pondok Pesantren Al-Hidayah Karangsuci said that reciting Hizb Sirrul Mashun as Mujahadah and Dzikr aims to protect oneself from danger. The reciting of Hizb Sirrul Mashun is especially 
important for Santri, junior and senior high school students, and university students because they will face various problems in seeking knowledge.

"Hizb Sirrul Mashun has an essential position for us. It as dhikr keeps us from injustice when seeking knowledge. It appears in a part of the Hizb often repeated.

$$
\text { الاعداؤنا لن يصلو ا الينا بالنفس و لا بالو اسطة لا قدرة لهم على ايصال السوء الينا بحال من }
$$

(Pengasuh 1, personal communication, 2020)

Then the Kyai said that Hizb Sirrul Mashun became daily dhikr. The Kyai of the Pondok Pesantren Al-Hidayah Karangsuci Purwokerto believes that when someone regularly recites the Hizb, he will be safe from various dangers and diseases, and all his wishes will come true (Pengasuh 2, personal communication, 2020).

"The benefits and virtues of Hizb Sirrul Mashun are many. Santri, someone looking for knowledge ( Thalabul Ilmi), faces many challenges. Therefore, reciting Hizb Sirrul Mashun can facilitate various matters such as financial and Mahabbah. The Kyai in Pondok Pesantren Mambaul Ulum Banyuwangi once said that if someone recites Hizb Sirrul Mashun for 41 days continuously, his sustenance will be abundant."

From the explanation, we know that resilience through reciting Hizb Sirrul Mashun is also strongly influenced by the social support implemented in the words of the Kyai, and social support is a driving force for students' resilience. Social support is a factor in the formation of resilience in individuals. Therefore, with social support, they get a positive impet us to overcome the problems they are experiencing (Karadag et al., 2019). By this opinion, Ruisoto stated in his article that social support has a crucial position as a protective factor in dealing with problems experienced by individuals in resilience (Ruisoto et al., 2020). Providing social support during a pandemic can increase the positive impact and personal resilience in dealing with problems (Wu et al., 2020).

The second is expressive meaning. After the researcher discusses the objective meaning of reciting Hizb Sirrul Mashun, He will explore its expressive meaning. According to Mannheim, expressive meaning is a meaning that the actor conveys to the audience. By uncovering the meaning, the researcher 
Alief Budiyono: Students Resilience Through Reciting Hizib Sirrul Mashun as A Living Qur'an Tradition in Pondok Pesantren al-Hidayah... (page 1-24)

finds that the actor's actions depend on his historical journey-his experience and knowledge (Mannheim, 1954).

The researchers obtained expressive meaning through direct interviews with Santri in Pondok Pesantren Al-Hidayah Karangsuci Purwokerto. After the interview, the researcher got data regarding the meaning of Hizb Sirrul Mashun, Muhammad Nur Salim, and Agus Maqruf when the interview stated:

Kang! I recite Hizb Sirrul Mashun because I obey the rules of Pondok Pesantren. We understand that if we don't recite the Hizb, we will be punished by standing in front of the Kyai's house (Ndalem). It is also a motivation for me to recite the Hizb regularly. Besides that, another thing that motivates me is to get closer to Allah SWT (Santri 5, personal communication, 2020).

First, I practice this tradition (recitation of Hizb Sirrul Mashun) because it is a regulation or obligation set by the Kyai. Second, I believe that this Hizb has many virtues (Fadhilah), especially safety. Moreover, I also feel calm when I recite this Hizb because many parts in the Hizb come from the Al-Qur'an (Santri 6, personal communication, 2020)

The expressive meaning that Santri 5 and Santri 6 show in interpreting the reciting of Hizb Sirrul Mashun at Pondok Pesantren Al-Hidayah is a symbol of the glorification for the regulations set by Pondok Pesantren Al-Hidayah Karangsuci Purwokerto. In addition, reciting the Hizb aims to get closer to Allah SWT. The statement conveyed by Santri 5 and Santri 6 confirmed the opinion of Deb (2016) on religiosity and spirituality as factors that could affect resilience (Deb et al., 2016).

As shown in Figure 1, spirituality and religiosity are significant sources of hope, peace, comfort, and forgiveness for oneself and society at large (Brewer-Smyth \& Koenig, 2014). Religiosity and spirituality have benefits in integral relationships (Budiyono, 2021). A person with good spiritual quality more significantly can deal with the pressures and problems he experiences because he will associate his life experiences with transcendental things (Permana, 2018).

Javanmard revealed that a person's level of faith affects the individual's mental condition. A person who has high faith can be calm and reduce the anxiety he experiences. In other words, the practice of religious beliefs, such as faith, possessed by individuals can form resilience in individuals (Javanmard, 2013). 
The tradition of reciting Hizb Sirrul Mashun is essential when it is associated with the resilience behavior of students (Santri). Through this tradition, students at least form several aspects in dealing with the COVID-19 pandemic. The first is emotional regulation. It is an individual skill to manage themselves. Therefore, they can always live life efficiently even under pressure. Resilient people have a range of skills to regulate their emotions, attention, and attitudes.

The second is impulse control. It is the skill to regulate attitudes. Resilient people can postpone their pleasures to do something better. The third is the skill to analyze problems accurately. Resilient people can think outside the box. Therefore, they can understand and overcome various issues.

Fourth is self-efficacy. It makes people confident to manage conditions and can overcome the problems. Resilient people who have confidence in themselves can build the confidence of others so that they have the opport unity to get success. Fifth is optimistic. It is the skill to think positively about his future and a good plan to achieve those goals.

Sixth is empathy. It is a skill to read other people's attitudes and understand their psychological state. Resilient people can form good bonds with others. The seventh is Achievement. It is a skill to increase the positive things in life and a condition to be ready to accept any challenges (Reivich \& Shatte, 2002).

Figure 1.

The Influence of Social Support, Spirituality, and Religiosity on Santri Resilience

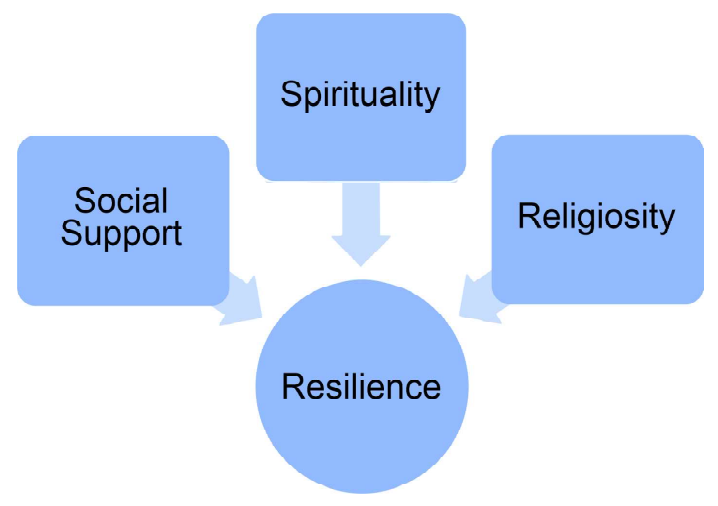


Alief Budiyono: Students Resilience Through Reciting Hizib Sirrul Mashun as A Living Qur'an Tradition in Pondok Pesantren al-Hidayah... (page 1-24)

The third is the meaning of documentary. After the exploration, the researcher will analyze the documentary meaning of reciting Hizb Sirrul Mashun. According to Mannheim, the documentary meaning is an implied meaning. The actor does not consciously know that his actions refer to the cultural system (Mannheim, 1954).

Universally, reciting the Hizb is a common practice among Muslims in various parts of the world such as reciting Hizb Nahdatul Wathan, Hizb Latif, Hizb al-Kahfi, Hizb as-Syifa, and so on. Among Pondok Pesantren based on Ahlu Sunnah Wal Jama'ah, the practices such as reciting Hizb are not strange thing.

Hizb recited at Pondok Pesnatren Wahid Hasyim in Yogyakarta is Hizb al-Bayumi. The Hizb recited in the Lombok region is Hizb Nahdathul Wathan. Reciting the Hizb is dhikr or Mujahadah carried out in Pondok Pesantren that adhere to the teachings of Ahlu Sunnah Wal Jama'ah. This reciting emphasizes that students always get closer to Allah SWT by carrying out dhikr. Dhikr is a tradition in various Pondok Pesantren from generation to generation, and the people still preserve it until now. So, it is not surprising that this dhikr often exists among Pondok Pesantren in Indonesia.

\section{Conclusion}

The research conducted at Pondok Pesantren Al-Hidayah Karangsuci Purwokerto on students' resilience through reciting Hizb Sirrul Mashun is as follows: First, students are worried about the covid-19 pandemic. Therefore, through reciting this Hizb, the students can carry out various positive adaptation processes during the Covid-19 Pandemic.

Second, on a practical level, Hizb Sirrul Mashun is accompanied by fasting for seven consecutive days-for new students who will meet the requirements. Students read the Hizb seven times a day. During these seven days, students must continuously fast and recite Hizb. If not, then the student repeats the practice from the beginning. Senior Santri lead the reciting Hizb Sirrul Mashun in the mosque. Students recite the Hizb after Isha prayer in congregation on Friday night at An-Nur Mosque.

Third, the reciting Hizb Sirrul Mashun, according to the sociological theory of Karl Mannheim, has three meanings, namely objective, expressive, and documentary. The objective meaning that emerges emphasizes that the 
reciting Hizb Sirrul Mashun is also strongly influenced by the social support implemented in the words of Kyai. The expressive meaning that emerges from the Santri also emphasizes that other factors influence the formation of resilience, namely aspects of religiosity and spirituality.

\section{E. Bibliography}

Abdullah, M. (2012). Fungsi Wirid dan Hizib Dalam Sastra Lisan Pesantren (Studi Kasus Wirid Asma'ul Husna dan Hizib Lathif di Brangsong Kendal). Universitas Diponegoro.

Adler, A. B., \& Saboe, K. N. (2017). How Organisations and Leaders Can Build Resilience: Lessons from high-risk occupations. In Managing for Resilience. Routledge.

Al-Baihaqi. (1408). Dalail al-Nubuwwah. Dar al-Kutub al-'Ilmiyyah.

As-Syafi'i, J. A. (n.d.). Al- Itqan Fi 'Ulumil Qur'an. Darul Fikri.

Barro, R. J., Ursúa, J. F., \& Weng, J. (2020). The Covid-19virus and the Great Influenza Pandemi: Lessons from the "Spanish Flu" for the Covid-19virus's Potential Effects on Mortality and Economic Activity (Working Paper No. 26866; Working Paper Series). National Bureau of Economic Research. https://doi.org/10.3386/w26866

Brewer-Smyth, K., \& Koenig, H. G. (2014). Could spirituality and religion promote stress resilience in survivors of childhood trauma? Issues in Mental Health Nursing, 35(4), 251-256. https://doi.org/10.3109/ 01612840.2013 .873101

Budiyono, A. (2021). Konseling di Lembaga Pemasyarakatan. STAIN Press. Budiyono, A., Sugiharto, D., Sutoyo, A., \& Rachman, M. (2020). Empirical Study: Cognitive Behavior Therapy (CBT) And Resilience of Prisoners before Being Released. International Journal of Innovative Science and Research Technology, 5(7), 1085-1091. https://doi.org/10.38124/ IJISRT20JUL572

Deb, S., McGirr, K., \& Sun, J. (2016). Spirituality in Indian University Students and its Associations with Socioeconomic Status, Religious Background, Social Support, and Mental Health. Journal of Religion and Health, 55(5), 1623-1641. https://doi.org/10.1007/s10943-0160207-x 
Alief Budiyono: Students Resilience Through Reciting Hizib Sirrul Mashun as A Living Qur'an Tradition in Pondok Pesantren al-Hidayah... (page 1-24)

Diclemente, R. J., \& John, S. S. (2009). Adolescent health; Understanding and preventing risk behaviors. Jossey-Bass.

Fathurrosyid, F. (2015). Tipologi Ideologi Resepsi Al quran di Kalangan Masyarakat Sumenep Madura. El-harakah (terakreditasi), 17(2), 218 239. https://doi.org/10.18860/el.v17i2.3049

Gomez-Molinero, R., Zayas, A., Ruiz-González, P., \& Guil, R. (2018). Optimism and resilience among university students. International Journal of Developmental and Educational Psychology. Revista INFAD de Psicología., 1, 147. https://doi.org/10.17060/ijodaep.2018.n1. v1.1179

Harapandi, D., A'dam, S., \& Habib, M. (2010). Reposisi Tarekat Hizib NW dalam Tarekat Mu'tabarah di Indonesia. Penamadani bekerjasama dengan STAI Al-Aqidah Al-Hasyimiyah Jakarta.

Hidayat, K. (1996). Memahami Bahasa Agama: Sebuah Kajian Hermeneutik. Paramadina.

Hidayatullah, S. (2017). Nilai-nilai Pendidikan Karakter Santri dalam Pelaksanaan Kegiatan Muroja'ah Juz 'Amma di Pondok Pesantren AlHidayah Karangsuci Purwokerto. IAIN Purwokerto.

Hou, X.-L., Wang, H.-Z., Guo, C., Gaskin, J., Rost, D. H., \& Wang, J.-L. (2017). Psychological resilience can help combat the effect of stress on problematic social networking site usage. Personality and Individual Differences, 109, 61-66. https://doi.org/10.1016/j.paid.2016.12.048

Ilyas, H. (2004). Studi Kitab Tafsir. Teras.

Imzi, A. H. H. (2017). Kaidah-Kaidah Penafsiran Pedoman Bagi Pengkaji Alquran. Lingkar Studi Alquran.

Iser, W. (1978). The Act of Reading; A Theory of Aesthetic Response. John Hopkins University Press.

Iswatunnisa, K. (2015). Keserasian Bunyi Akhir dalam Alquran Surah alInsyirah (Kajian Aspek Fonologi terhadap Alquran). UIN Sunan Kalijaga Yogyakarta.

Javanmard, G. H. (2013). Religious Beliefs and Resilience in Academic Students. Procedia - Social and Behavioral Sciences, 84, 744-748. https://doi.org/10.1016/j.sbspro.2013.06.638

Jin, Y.-H., Cai, L., Cheng, Z.-S., Cheng, H., Deng, T., Fan, Y.-P., Fang, C., Huang, D., Huang, L.-Q., Huang, Q., Han, Y., Hu, B., Hu, F., Li, B.- 
H., Li, Y.-R., Liang, K., Lin, L.-K., Luo, L.-S., Ma, J., ... , for the Zhongnan Hospital of Wuhan University Novel Covid-19virus Management and Research Team, Evidence-Based Medicine Chapter of China International Exchange and Promotive Association for Medical and Health Care (CPAM). (2020). A rapid advice guideline for the diagnosis and treatment of 2019 novel covid-19virus (2019$\mathrm{nCoV}$ ) infected pneumonia (standard version). Military Medical Research, 7(1), 4. https://doi.org/10.1186/s40779-020-0233-6

Jurjewicz, H. (2016). How spirituality leads to resilience a case study of immigrants. European Journal of Science and Theology, 12(4).

Karadag, E., Ugur, O., Mert, H., \& Erunal, M. (2019). The Relationship Between Psychological Resilience and Social Support Levels in Hemodialysis Patients. The Journal of Basic and Clinical Health Sciences, 3. https://doi.org/10.30621/jbachs.2019.469

Madjid, M., Safavi-Naeini, P., Solomon, S. D., \& Vardeny, O. (2020). Potential Effects of Covid-19viruses on the Cardiovascular System: A Review. JAMA Cardiology, 5(7), 831-840. https://doi.org/10.1001/ jamacardio.2020.1286

Maliki, M. 'alawi. (n.d.). Mafahim Yajibu an-Tushoha. Darr Jawami’ul Kalim. Mannheim, K. (1954). Essay on The Sociology of Knowledge. Brodway House.

Missasi, V., \& Izzati, I. D. C. (2019). Faktor-faktor yang Mempengaruhi Resiliensi. Prosiding Seminar Nasional Magister Psikologi.

Noor, M., \& Muslihan, H. (2004). Mengenal Tarekat Hizib Nahdlatul Wathan. Pondok Pesantren Nahdlatul Wathan Jakarta.

Noor, M., Muslihan, H., \& Zuhdi, M. H. (2004). Visi Kebangsaan Religius; Refleksi Pemikiran dan Perjuangan Tuan Guru Kyai Haji Muhammad Zainuddin Abdul Madjid 1904-1997. Logos Wacana Ilmu.

Pengasuh 1. (2020). [Personal communication].

Permana, D. (2018). Peran Spiritualitas dalam Meningkatkan Resiliensi pada Residen Narkoba. Syifa al-Qulub, 2(2), 75-88. https://doi.org/ $10.15575 /$ saq.v2i2.2972

Pradopo, R. D. (2007). Beberapa Teori Sastra: Metode Kritik dan Penerapannya. Pustaka Pelajar.

Qayyim, I. (n.d.). Zaad Al-Ma'ad Fi Hadyi Khairil Ibad. Beragam. 
Alief Budiyono: Students Resilience Through Reciting Hizib Sirrul Mashun as A Living Qur'an Tradition in Pondok Pesantren al-Hidayah... (page 1-24)

Ratna, N. K. (2009). Teori, Metode, dan Teknik Penelitian Sastra. Pustaka Pelajar.

Reisnick, B., Gwyther, L. P., \& Roberto, K. (2011). Resilience in Aging: Concepts, research, and outcomes. Springer Science \& Business Media.

Reivich, K., \& Shatte, A. (2002). The resilience faktor: 7 essential skills for overcoming life's inevitable obstacle. Broadway Books.

Ruisoto, P., Contador, I., Fernández-Calvo, B., Serra, L., Jenaro, C., Flores, N., Ramos, F., \& Rivera-Navarro, J. (2020). Mediating effect of social support on the relationship between resilience and burden in caregivers of people with dementia. Archives of Gerontology and Geriatrics, 86, 103952. https://doi.org/10.1016/j. archger.2019.103952

Rutter, M. (2006). Implications of resilience concepts for scientific understanding. Annals of the New York Academy of Sciences, 1094, 1-12. https://doi.org/10.1196/annals.1376.002

Santri 1. (2020). [Personal communication].

Santri 2. (2020). [Personal communication].

Santri 3. (2020). [Personal communication].

Santri 4. (2020). [Personal communication].

Santri 5. (2020). [Personal communication].

Santri 6. (2020). [Personal communication].

Salim, \& Syahrun. (2012). Metodologi Penelitian Kualitatif. Ciptapustaka Media.

Shihab, M. Q. (1999). Menyelami Kalam Tuhan. Pustaka Pelajar.

Soehadha, Mohd. (2012). Metode Penelitian Sosial Kualitatif untuk Studi Agama. SUKA Press.

Umar. (2010, January 9). Definisi Ilmu Hizib. RASA SEJATI. https:// rasasejati.id/kajian-ilmu-ghoib/hizib-ratib/

Veselska, Z., Geckova, A. M., Orosova, O., Gajdosova, B., van Dijk, J. P., \& Reijneveld, S. A. (2009). Self-esteem and resilience: The connection with risky behavior among adolescents. Addictive Behaviors, 34(3), 287-291. https://doi.org/10.1016/j.addbeh.2008.11.005

Waxman, H. C., \& Yolanda, N. P. (2013). Review of research on educational resilience. Institute of Education Science. 
Wong, P., Wong, L., \& Scott, C. (2006). Beyond Stress and Coping: The Positive Psychology of Transformation (pp. 1-26). https://doi.org/ 10.1007/0-387-26238-5_1

Wu, A. W., Connors, C., \& Everly, G. S. (2020). COVID-19: Peer Support and Crisis Communication Strategies to Promote Institutional Resilience. Annals of Internal Medicine, 172(12), 822-823. https://doi.org/ 10.7326/M20-1236

Zaman, A. R. B. (2019). Resepsi Alquran Di Pondok Pesantren Karangsuci Purwokerto [Skripsi, IAIN Purwokerto]. http://repository. iainpurwokerto.ac.id/5114/

Zaman, A. R. B. (2020). Tipologi dan simbolisasi resepsi Alquran di pondok pesantren miftahul huda rawalo banyumas. Aqlam: Journal of Islam and Plurality, 5(2), Article 2. https://doi.org/10.30984/ajip.v5i2.1375 